\title{
Soil moisture and land use are major determinants of soil microbial community composition and biomass at a regional scale in northeastern China
}

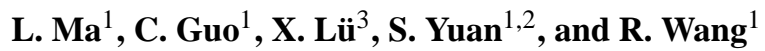 \\ ${ }^{1}$ State Key Laboratory of Vegetation and Environmental Change, Institute of Botany, Chinese Academy of Sciences, \\ Beijing, 100093, China \\ ${ }^{2}$ University of Chinese Academy of Sciences, Beijing, 100049, China \\ ${ }^{3}$ State Key Laboratory of Forest and Soil Ecology, Institute of Applied Ecology, Chinese Academy of Sciences, \\ Shenyang, 110164, China
}

Correspondence to: R. Wang (wangrz@ibcas.ac.cn)

Received: 12 November 2014 - Published in Biogeosciences Discuss.: 18 December 2014

Revised: 8 April 2015 - Accepted: 9 April 2015 - Published: 30 April 2015

\begin{abstract}
Global environmental factors impact soil microbial communities and further affect organic matter decomposition, nutrient cycling and vegetation dynamic. However, little is known about the relative contributions of climate factors, soil properties, vegetation types, land management practices and spatial structure (which serves as a proxy for underlying effects of temperature and precipitation for spatial variation) on soil microbial community composition and biomass at large spatial scales. Here, we compared soil microbial communities using phospholipid fatty acid method across 7 land use types from 23 locations at a regional scale in northeastern China $(850 \times 50 \mathrm{~km})$. The results showed that soil moisture and land use changes were most closely related to microbial community composition and biomass at the regional scale, while soil total $\mathrm{C}$ content and climate effects were weaker but still significant. Factors such as spatial structure, soil texture, nutrient availability and vegetation types were not important. Higher contributions of grampositive bacteria were found in wetter soils, whereas higher contributions of gram-negative bacteria and fungi were observed in drier soils. The contributions of gram-negative bacteria and fungi were lower in heavily disturbed soils than historically disturbed and undisturbed soils. The lowest microbial biomass appeared in the wettest and driest soils. In conclusion, dominant climate and soil properties were not the most important drivers governing microbial community composition and biomass because of inclusion of irrigated and managed practices, and thus soil moisture and land use
\end{abstract}

appear to be primary determinants of microbial community composition and biomass at the regional scale in northeastern China.

\section{Introduction}

The soil microbial community plays important roles in regulating organic matter decomposition, nutrient cycling, soil structural formation and even plant interactions (Wardle et al., 2004; Harris et al., 2009). At the same time, it is subjected to the influences of environmental conditions, land use and spatial structure (Yang et al., 2013). Although there is a growing body of evidence indicating that climate, soil property, vegetation, spatial structure and land use are the most important determinants of the global and regional patterns in soil microbial communities (Kreft and Jetz, 2007; Nielsen et al., 2010; Zinger et al., 2011; Pasternak et al., 2013; Tsiknia et al., 2014), how to disentangle the contributions of multiple drivers to microbial community composition and biomass remains unclear.

Regional climate factors exert major influences on distributions of microbial communities by determining temperature and soil water availability along topographic gradients (Hackl et al., 2005; Carletti et al., 2009; Brockett et al., 2012). Drenovsky et al. (2010) and Brockett et al. (2012) found that soil water availability was an important determinant of microbial community composition, and fun- 
gal : bacterial biomass ratios decreased with increased soil water saturation at regional scales. In different types of natural Austrian forests, Hackl et al. (2005) showed that mean annual temperature was the major factor influencing microbial community composition in zonal forest but that soil water availability was most closely correlated with microbial community in azonal forests.

Soil property has been found to strongly correlate with soil microbial community structure and abundance at regional scales. Previous studies have reported that soil texture, organic matter content, $\mathrm{N}$ availability and $\mathrm{pH}$ exhibited dominant effects on soil microbial community composition, while climatic effects were weaker but still significant at regional scales (Šantrucková et al., 2003; Brockett et al., 2012; Yang et al., 2013; Tsiknia et al., 2014). For example, Tsiknia et al. (2014) identified soil total organic C, $\mathrm{pH}$ and geographic distance as the most important determinants of microbial community abundance at the watershed scale in Greece. Moreover, plant communities differing in species composition are likely to produce litter and vary in their chemical composition, which may subsequently influence soil microbial community composition (Zhang et al., 2005a; Eskelinen et al., 2009). As a biotic driver, plants may also exert great effects on soil microbial communities by controlling allocation of belowground photosynthates (Kaiser et al., 2011).

Spatial structure (which serves as a proxy for underlying effects of temperature and precipitation for spatial variation) influences the organization of community as a functional variable in a different way to which the background in which biological and environmental factors act on community and ecosystem (Borcard et al., 1992). Recent research has shown there to be strong autocorrelations between microbial groups, and geographic distance could explain a high proportion of microbial community variation (Tsiknia et al., 2014). However, Fierer and Jackson (2006) claimed that soils with similar environmental characteristics have similar bacterial communities regardless of geographic distance at continental scales. Using spatial trend surface analysis, Drenovsky et al. (2010) also found that spatial structure did not influence microbial community composition across three biogeographical provinces in California.

At regional scales, land use change is the major reason for spatial heterogeneity. It has been shown that land use changes lead to great variation in soil microbial community composition in diverse ecosystems (Drenovsky et al., 2010), though their impacts depend on many factors, including the original vegetation that is being replaced and associated land management practices such as tillage and fallow periods, as well as related water and nutrient applications such as irrigation and fertilization (Scanlon et al., 2007; Ma et al., 2013; Yang et al., 2013; Chen et al., 2014). In one study, Drenovsky et al. (2010) reported that distinct microbial communities were associated with land use types and disturbance at the regional scale in California. Tillage influences multi-

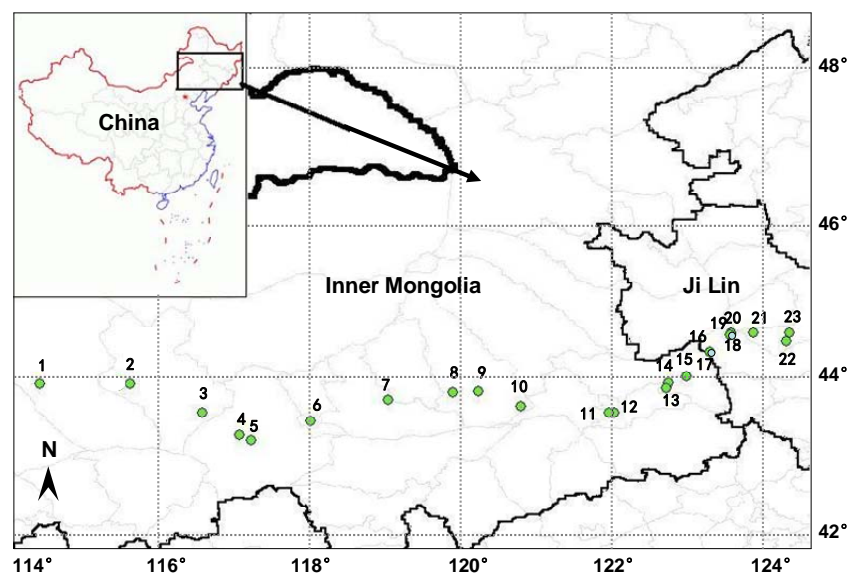

Figure 1. Sample locations (1-23; see Table 1) at a regional scale in northeastern China.

ple soil physical and chemical properties, disrupts soil fungal hyphae (Evans and Miller, 1990), and alters microbial community composition (Ingram et al., 2008; Drenovsky et al., 2010). Recently, changes in land use have occurred in temperate areas of northeastern China as a result of expansion of farmlands and grazed rangelands at the expense of natural habitats; however, little is known about soil microbial community composition to land use changes at regional scales.

In this study we compare microbial community composition and biomass from 23 locations across 7 land use types (i.e., rangeland, artificial grassland, grazed rangeland, farmland, returned cropland, woodland and rice field) at a regional scale in the Northeast China Transect (NECT). The NECT is identified as a midlatitude semiarid terrestrial transect and is sensitive to climate change and disturbance, and thus provides an ideal setting to investigate distribution patterns of soil microbial community. Our work specifically aimed at disentangling the contributions of climate, soil properties, vegetation types, spatial structure and land use on microbial community composition and biomass at the regional scale. We hypothesize that climate and soil properties are the primary drivers affecting soil microbial community composition and biomass, because the climatic gradient, especially precipitation, is one of the most notable features in this region (Wang et al., 2003).

\section{Materials and methods}

\subsection{Study locations}

The field study was conducted on a regional scale $\left(43^{\circ} 12^{\prime}-\right.$ $44^{\circ} 36^{\prime} \mathrm{N}, 114^{\circ} 34^{\prime}-124^{\circ} 18^{\prime} \mathrm{E}$ ) across Jilin province and Inner Mongolia (about $850 \mathrm{~km}$ from east to west, and $50 \mathrm{~km}$ from north to south) with 23 locations in the Northeast China Transect (NECT) (Table 1, Fig. 1). The NECT was identified as a core project of International Geosphere-Biosphere Pro- 
Table 1. Sample locations (1-23), coordinates of the sample location, land use types, vegetation types and number of replicates $(n)$.

\begin{tabular}{|c|c|c|c|c|c|}
\hline Location & No. & Coordinates & Land use type & Vegetation type & $n$ \\
\hline Baogedawula & 1 & $43^{\circ} 56^{\prime} \mathrm{N}, 114^{\circ} 34^{\prime} \mathrm{E}$ & Rangeland & Desert steppe & 8 \\
\hline \multirow[t]{2}{*}{ Dabuxiletu } & 2 & $43^{\circ} 55^{\prime} \mathrm{N}, 115^{\circ} 44^{\prime} \mathrm{E}$ & Rangeland & Desert steppe & 8 \\
\hline & 2 & & Grazed rangeland & Desert steppe & 8 \\
\hline \multirow[t]{2}{*}{ Aqiwula } & 3 & $43^{\circ} 33^{\prime} \mathrm{N}, 116^{\circ} 40^{\prime} \mathrm{E}$ & Rangeland & Steppe & 10 \\
\hline & 3 & & Woodland & Wood and shrub & 8 \\
\hline Dalainuori & 4 & $43^{\circ} 16^{\prime} \mathrm{N}, 117^{\circ} 09^{\prime} \mathrm{E}$ & Rangeland & Steppe & 8 \\
\hline Sanyi & 5 & $43^{\circ} 12^{\prime} \mathrm{N}, 117^{\circ} 18^{\prime} \mathrm{E}$ & Woodland & Wood and shrub & 8 \\
\hline \multirow[t]{2}{*}{ Xinchengzi } & 6 & $43^{\circ} 27^{\prime} \mathrm{N}, 118^{\circ} 04^{\prime} \mathrm{E}$ & Rangeland & Steppe & 14 \\
\hline & 6 & & Returned cropland & Alfalfa & 8 \\
\hline \multirow[t]{2}{*}{ Xinfuzhilu } & 7 & $43^{\circ} 43^{\prime} \mathrm{N}, 119^{\circ} 04^{\prime} \mathrm{E}$ & Grazed rangeland & Steppe (site 1) & 4 \\
\hline & 7 & & & Steppe (site 2) & 4 \\
\hline \multirow[t]{2}{*}{ Tianshan } & 8 & $43^{\circ} 50^{\prime} \mathrm{N}, 119^{\circ} 55^{\prime} \mathrm{E}$ & Rangeland & Steppe & 8 \\
\hline & 8 & & Returned cropland & Almond & 16 \\
\hline \multirow[t]{2}{*}{ Tianshan } & 9 & $43^{\circ} 50^{\prime} \mathrm{N}, 120^{\circ} 15^{\prime} \mathrm{E}$ & Rangeland & Steppe & 9 \\
\hline & 9 & & Returned cropland & Almond & 9 \\
\hline \multirow[t]{3}{*}{ Shaogen } & 10 & $43^{\circ} 38^{\prime} \mathrm{N}, 120^{\circ} 47^{\prime} \mathrm{E}$ & Rangeland & Steppe (site 1) & 8 \\
\hline & 10 & & & Steppe (site 2) & 8 \\
\hline & 10 & & Farmland & Corn & 8 \\
\hline \multirow[t]{3}{*}{ Molimiao } & 11 & $43^{\circ} 34^{\prime} \mathrm{N}, 121^{\circ} 55^{\prime} \mathrm{E}$ & Rangeland & Steppe (site 1) & 8 \\
\hline & 11 & & & Steppe (site 2) & 8 \\
\hline & 11 & & Farmland & Corn & 8 \\
\hline Yuxin & 12 & $43^{\circ} 34^{\prime} \mathrm{N}, 121^{\circ} 59^{\prime} \mathrm{E}$ & Rice field & Rice & 14 \\
\hline Baixingtu & 13 & $43^{\circ} 52^{\prime} \mathrm{N}, 122^{\circ} 41^{\prime} \mathrm{E}$ & Woodland & Wood and shrub & 8 \\
\hline \multirow[t]{3}{*}{ Baolongshan } & 14 & $43^{\circ} 56^{\prime} \mathrm{N}, 122^{\circ} 42^{\prime} \mathrm{E}$ & Rangeland & Meadow (site 1) & 7 \\
\hline & 14 & & & Meadow (site 2) & 6 \\
\hline & 14 & & Farmland & Corn & 8 \\
\hline \multirow[t]{4}{*}{ Jiamatu } & 15 & $44^{\circ} 01^{\prime} \mathrm{N}, 122^{\circ} 56^{\prime} \mathrm{E}$ & Rangeland & Meadow (site 1) & 8 \\
\hline & 15 & & & Meadow (site 2) & 8 \\
\hline & 15 & & Farmland & Corn & 8 \\
\hline & 15 & & & Red bean & 7 \\
\hline \multirow[t]{2}{*}{ Taipingchuan } & 16 & $44^{\circ} 21^{\prime} \mathrm{N}, 123^{\circ} 14^{\prime} \mathrm{E}$ & Rangeland & Meadow & 9 \\
\hline & 16 & & Rice field & Rice & 9 \\
\hline \multirow[t]{3}{*}{ Yaojingzinan } & 17 & $44^{\circ} 21^{\prime} \mathrm{N}, 123^{\circ} 14^{\prime} \mathrm{E}$ & Woodland & Wood and shrub (site 1 ) & 11 \\
\hline & 17 & & Woodland & Wood and shrub (site 2) & 10 \\
\hline & 17 & & Farmland & Peanut & 8 \\
\hline \multirow{5}{*}{ Yaojingzi } & 18 & $44^{\circ} 34^{\prime} \mathrm{N}, 123^{\circ} 29^{\prime} \mathrm{E}$ & Rangeland & Meadow (site 1) & 8 \\
\hline & 18 & & & Meadow (site 2) & 7 \\
\hline & 18 & & Farmland & Peanut & 8 \\
\hline & 18 & & & Mung bean & 8 \\
\hline & 18 & & & Corn & 8 \\
\hline Yaojingzi & 19 & $44^{\circ} 35^{\prime} \mathrm{N}, 123^{\circ} 30^{\prime} \mathrm{E}$ & Rangeland & Meadow & 14 \\
\hline \multirow[t]{3}{*}{ Yaojingzi } & 20 & $44^{\circ} 34^{\prime} \mathrm{N}, 123^{\circ} 31^{\prime} \mathrm{E}$ & Artificial grassland & Meadow (site 1) & 7 \\
\hline & 20 & & & Meadow (site 2) & 8 \\
\hline & 20 & & Farmland & Corn & 8 \\
\hline \multirow[t]{4}{*}{ Wulanaodu } & 21 & $44^{\circ} 36^{\prime} \mathrm{N}, 123^{\circ} 48^{\prime} \mathrm{E}$ & Rangeland & Meadow (site 1) & 8 \\
\hline & 21 & & & Meadow (site 2) & 8 \\
\hline & 21 & & Farmland & Corn & 7 \\
\hline & 21 & & Woodland & Wood and shrub & 9 \\
\hline Chaganhua & 22 & $44^{\circ} 35^{\prime} \mathrm{N}, 124^{\circ} 16^{\prime} \mathrm{E}$ & Rangeland & Meadow (site 1) & 8 \\
\hline \multirow[t]{6}{*}{ Wulantuga } & 22 & $44^{\circ} 28^{\prime} \mathrm{N}, 124^{\circ} 18^{\prime} \mathrm{E}$ & Rangeland & Meadow (site 2) Meadow & 8 \\
\hline & 23 & & & & 8 \\
\hline & 23 & & Farmland & Corn & 6 \\
\hline & 23 & & & Peanut & 6 \\
\hline & 23 & & Woodland & Wood and shrub & 8 \\
\hline & & & & Total & 451 \\
\hline
\end{tabular}


gramme (IGBP), which represents an array of regional-scale gradients on all continents that vary in major environmental variables (Koch et al., 1995). This area has a continental monsoon climate, with large seasonal temperature and precipitation gradients. Long-term (1950-2000) mean annual temperature, precipitation and radiative dry index at this spatial scale range from approximately 1.3 to $6.8^{\circ} \mathrm{C}, 237$ to $472 \mathrm{~mm}$ and 0.91 to 1.44 , respectively. The elevation gradients range from 140 to $1309 \mathrm{~m}$ (http://www.worldclim.com; Zhang et al., 1997; Appendix A1). Mean soil total C, N and $\mathrm{C}: \mathrm{N}$ varied 3.3-fold, 2.4-fold and 2.7-fold, respectively, across the region. Overall, there were 7.4-fold and 2.8-fold differences in soil water content and water holding capacity, respectively, whereas soil origin and $\mathrm{pH}$ differed only slightly (Appendix A1).

Spatial climatic variability, especially precipitation, is one of the most notable features of the transect. Due to the large decrease in precipitation from the east (Jilin province) to the west (Inner Mongolia), vegetation vary gradually from moist meadows in the east to typical steppes and desert steppes in the west, with farmlands, returned croplands and woodlands spread evenly across the gradient (Wang et al., 2003, 2011; Appendix A1). All farmlands were irrigated only a few times (2-3 times) during the growing season, and rice field was flood-irrigated. The regions have remarkable variations in climate, land use types and vegetation types, which make it an ideal region for studying the primary factors driving soil microbial community composition and biomass. Detailed descriptions of land use types, vegetation types and soil properties can be found here in Table 1 and Appendix A1 as well as in Zhang et al. (1997) and Ni and Zhang (2000).

\subsection{Soil samplings}

Four hundred fifty-one soil samples from 23 locations including 7 land use types were collected along the NECT in 1218 July 2012. Between 6 and 16 soil core samples were collected randomly per site $(100 \times 100 \mathrm{~m})$ for determination of soil microbial communities (Table 1).

The samples were taken with a cylindrical soil sampler ( $5 \mathrm{~cm}$ inner diameter, $15 \mathrm{~cm}$ length) for the $0-15 \mathrm{~cm}$ layer, and then immediately preserved at $4{ }^{\circ} \mathrm{C}$ in a cooler for transport to the laboratory within 1 week of collection. The fresh samples were processed using a $2 \mathrm{~mm}$ sieve and manually cleaned of any visible plant tissues. Two subsamples of each sample were obtained: one was air-dried for routine soil analyses and the other was stored at $-70^{\circ} \mathrm{C}$ for phospholipid fatty acids analysis.

\subsection{Soil microbial community analysis}

Phospholipid fatty acids (PLFAs) were extracted and quantified from $8.0 \mathrm{~g}$ (dry weight equivalent) of soils using a procedure described by Bossio and Scow (1998). The separation and identification of extracted PLFAs were carried out according to the standard protocol of the Sherlock Microbial Identification System $\mathrm{V}_{4.5}$ (MIDI) and a gas chromatograph (Agilent 6850, USA). "A $: \mathrm{B} \omega \mathrm{C}$ " represents the number of carbons in the compound: the number of double bonds in the carbon chain, followed by double-bond location from the methyl $(\omega)$ end of the molecule (Bossio and Scow, 1998). Cis and trans conformations are indicated by the suffixes c and t. The prefixes a and i indicate anteiso and iso branching, $10 \mathrm{Me}$ specifies a methyl group on the 10th carbon from the carboxyl end of the molecule, $\mathrm{OH}$ indicates a hydroxyl group, and cy indicates cyclopropane fatty acids. In addition, the fatty acids "sum" indicates that imperfect peak separation occurs and refers to two or more fatty acids that have the same retention time (Drenovsky et al., 2004).

Thirty-one fatty acids were included in the analyses. (1) Branched fatty acids indicative of gram-positive bacteria: a13:0, i14:0, i15:0, i16:0, i17:0 and a17:0; (2) monounsaturated fatty acids indicative of gram-negative bacteria: $16: 1 \omega 7 \mathrm{c}, 17: 1 \omega 8 \mathrm{c}, 18: 1 \omega 5 \mathrm{c}, 18: 1 \omega 9 \mathrm{t}, 17: 0 \mathrm{cy}$ and $19: 0 \mathrm{cy}$ (Frostegård et al., 1993, 1996); (3) saturated fatty acid (common in soil microorganisms): 14:0, 15:0, 16:0, 17:0, 18:0 and $20: 0$; (4) two fatty acids $(18: 2 \omega 6 \mathrm{c}, 18: 1 \omega 9 \mathrm{c})$ were chosen to represent the fungi (Frostegård et al., 2011); and (5) actinomycetes was represented by 10Me 17:0 fatty acid. The fatty acids $14: 2 \omega 6 \mathrm{c}$ and $14: 1 \omega 8 \mathrm{c}$ were found in only three samples and were thus excluded from the data set. The ratio of $17: 0 \mathrm{cy}(17 \mathrm{cy})$ to $16: 1 \omega 7 \mathrm{c}$ (precursor) was used as an indicator of physiological stress (Knivett and Cullen, 1965). The viable microbial biomass was calculated by summing concentration of all fatty acids detected in each soil samples (White et al., 1979). Total percentages of fatty acid identified for each microbial group were calculated to represent their relative contributions to the total microbial biomass. The fungal : bacterial fatty acid (gram-positive + gram-negative bacteria) ratio was also included in the data analysis (Frostegård et al., 1996).

\subsection{Soil property analyses}

Soil inorganic $\mathrm{N}\left(\mathrm{NH}_{4}^{+}-\mathrm{N}+\mathrm{NO}_{3}^{-}-\mathrm{N}\right)$ was extracted with $2 \mathrm{M} \mathrm{KCl}$ solution, and the extractant was determined using a flow injection autoanalyzer (FIAstar 5000, Denmark). Soil $\mathrm{pH}$ was measured at a soil : water ratio of $1: 2.5$ with a $\mathrm{pH}$ electrode (PHS 29, China). Soil total C and N content were measured using an elemental analyzer (Elemetaranalysator vario Max CN, Germany). Soil texture was determined by the optical size analyzer (Mastersizer 2000, England). Gravimetric soil water content was measured by oven-drying samples at $105^{\circ} \mathrm{C}$ for $24 \mathrm{~h}$. Soil water holding capacity was measured by means of the Wilcox method (Wilcox, 1962).

\subsection{Statistical analyses}

Unconstrained ordination (correspondence analysis: CA) was used to compare soil microbial communities among 
samples $(n=451)$ using the Canoco for Windows 4.5 package (Ithaca, NY, USA). CA is an indirect gradient analysis method which can provide the basic overview of soil samples and maximize the correlation between fatty acids and samples (Lepš and Smilauer, 2003). Constrained ordination (canonical correspondence analysis: CCA) was used to represent the relationships among environmental factors (habitat, land management, spatial structure), sample patterns and fatty acids distributions (Lepš and Smilauer, 2003). Qualitative factors were coded for the program using a set of "dummy factors". That is, if a sample has a particular value of the factor, then the corresponding dummy factor has the value 1.0 and the other dummy factors have a value of 0.0 for the same sample.

In order to separate the effects of environmental factors on microbial communities, the variation partitioning procedure with CCA was used in the analysis (Borcard et al., 1992). The environmental factors were divided into three groups: (1) habitat (mean annual temperature, mean annual precipitation, radiative dry index, elevation, soil texture, $\mathrm{pH}$ class, soil $\mathrm{N}$ availability, soil $\mathrm{C}$ and $\mathrm{N}$ content, soil $\mathrm{C}: \mathrm{N}$, water holding capacity), (2) land management (tillage, grazing, historical tillage, flooding), and (3) spatial structure ( $x, y, x y, x^{2}, y^{2}$, $\left.x^{2} \mathrm{y}, x y^{2}, x^{3}, y^{3}\right)$. The third group consisted of nine terms, in which latitudinal $(x)$ and longitudinal $(y)$ coordinates were used to calculate a cubic trend surface. Spatial trend surface analysis is one of the quantitative ecological methods used to study the relation between spatial structure and species abundance distribution in community (Legendre, 1990). The variation partitioning procedure decomposed the total variability into eight parts: individual effect of habitat $\left(\mathrm{X}_{1}\right)$, land management $\left(\mathrm{X}_{2}\right)$, spatial structure $\left(\mathrm{X}_{3}\right)$, combined effects of habitat and land management $\left(\mathrm{X}_{4}\right)$, combined effects of land management and spatial structure $\left(\mathrm{X}_{5}\right)$, combined effects of habitat and spatial structure $\left(\mathrm{X}_{6}\right)$, combined effects of the three groups of environmental factors $\left(\mathrm{X}_{7}\right)$, and residual variation $\left(\mathrm{X}_{8}\right)$. A complete explanation of these partitioning analyses can be found in Lepš and Smilauer (2003).

Stepwise multiple linear analyses were used to determine the relationships of soil microbial community composition and biomass or the contribution of each microbial group with environmental factors. Differences among the sites in soil microbial biomass and contribution of each microbial group were tested using one-way ANOVA. Data management and statistical analyses were performed using SPSS 17.0 software (SPSS, Chicago, IL, USA).

\section{Results}

\subsection{Variation in soil microbial communities}

The first axis of CA ordination explained $27.5 \%$ of the variation in microbial community composition, mainly reflecting soil moisture gradients and land disturbance intensity
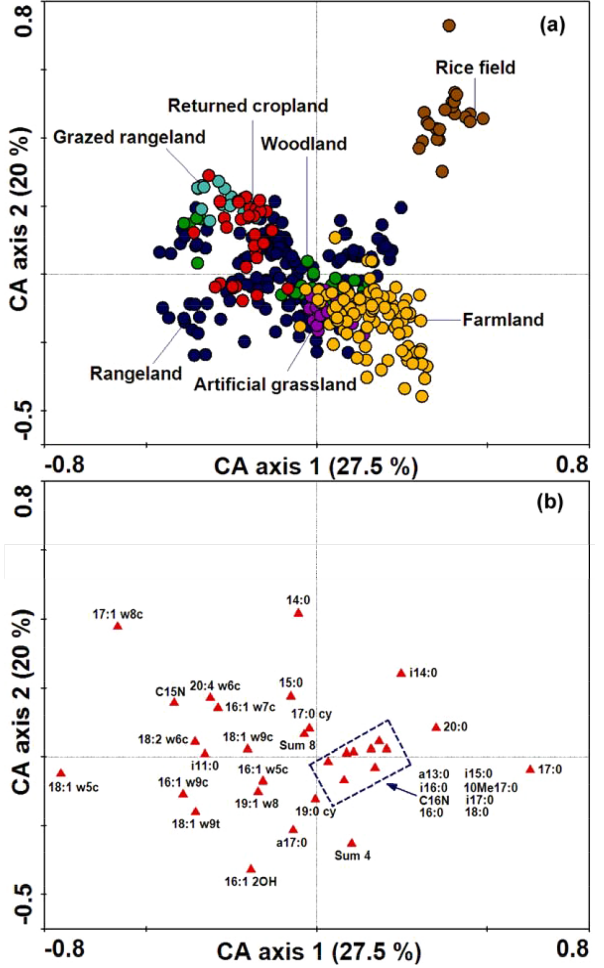

Figure 2. Ordination plots of correspondence analysis (CA) of all samples and fatty acids. (a) Ordination plot of 451 samples scores across 7 land use types (rangeland, artificial grassland, grazed rangeland, farmland, returned cropland, woodland and rice field). (b) Ordination plot of 31 fatty acids scores. The fatty acids scores are near the points for samples in which they occur with the highest relative contributions.

(Fig. 2a, b). Wetter soils (e.g., rice field, moisture rangeland) and heavily disturbed soils (e.g., farmland) with more branched fatty acids (gram-positive bacteria: a13:0, i14:0, i15:0, i16:0, i17:0) and saturated fatty acids (14:0, 15:0, 16:0, $17: 0,18: 0,20: 0)$ were positioned along the right side of the first axis. Drier soils and lightly and historically disturbed soils (e.g., dry rangeland, grazed rangeland, returned cropland) with more fungal $(18: 2 \omega 6 \mathrm{c}, 18: 1 \omega 9 \mathrm{c})$ and monounsaturated fatty acids (gram-negative bacteria: $16: 1 \omega 7 \mathrm{c}, 16: 1 \omega 9 \mathrm{c}$, $17: 1 \omega 8 \mathrm{c}, 18: 1 \omega 5 \mathrm{c}, 18: 1 \omega 9 \mathrm{t})$ were plotted along the left side of the first axis.

The second axis of CA ordination described $20 \%$ of the variation in the composition, mainly associated with management practices and spatial variation. In heavily disturbed habitats, the positions of flood-irrigated rice field and farmland were separated along the second axis (Fig. 2a). 

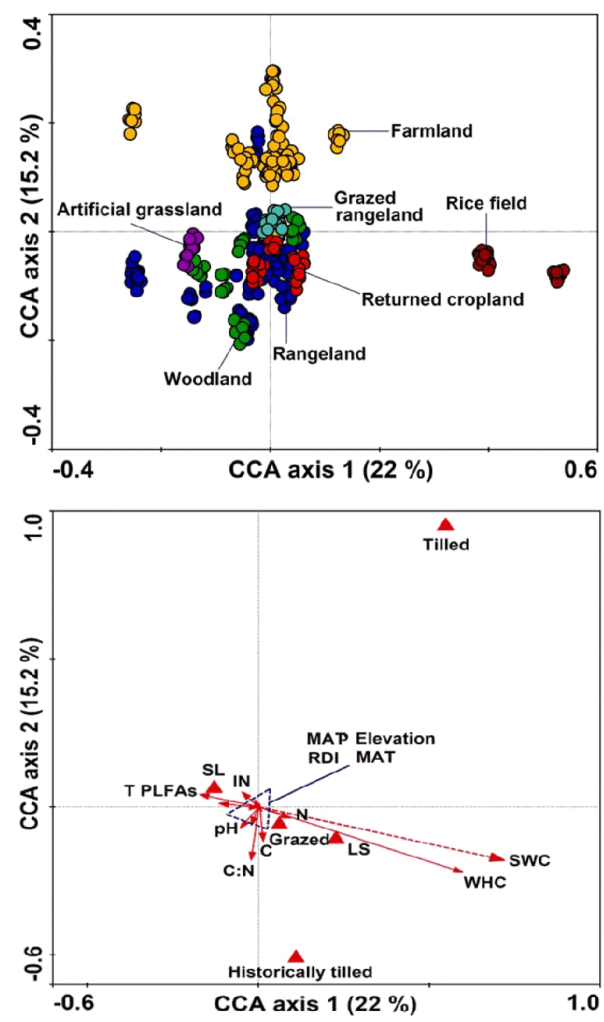

Figure 3. Ordination plots of canonical correspondence analysis (CCA) of all samples and environmental factors. (a) Ordination plot of 451 samples scores across 7 land use types. (b) Ordination plot of habitat and management factors scores in which spatial structure was run as a covariate. Mean annual temperature (MAT), mean annual precipitation (MAP), radiative dry index (RDI), elevation, soil water content (SWC, including natural precipitation and managed inputs), soil inorganic $\mathrm{N}(\mathrm{IN})$, soil total $\mathrm{C}$ and $\mathrm{N}(\mathrm{C}, \mathrm{N})$, soil $\mathrm{C}: \mathrm{N}$, total (T) PLFAs, water holding capacity (WHC) and soil $\mathrm{pH}$ were quantitative environmental factors, and soil texture (loamy sand, LS; sandy loam, SL), land management practices (tilled, historically tilled, grazed) were qualitative (nominal) environmental factors. Quantitative factors were plotted as vectors, and qualitative factors were plotted as centroids.

\subsection{Relationship between microbial communities and environmental factors}

Soil microbial community composition across seven land use types at the regional scale was distinguished by environmental factors with the CCA ordination (Fig. 3a, b). The first axis explained $22 \%$ of the variation in microbial community composition, mainly associated with water regime (i.e., soil water availability) and water holding capacity. The second axis described $15.2 \%$ of the variation, primarily related to management intensity (tillage $>$ historical tillage or grazing). Climate factors (mean annual precipitation and temperature, radiative dry index, elevation) did not show strong relationships with distribution of microbial communities. Factors such as soil texture (sandy loam), soil inorganic $\mathrm{N}$ con-

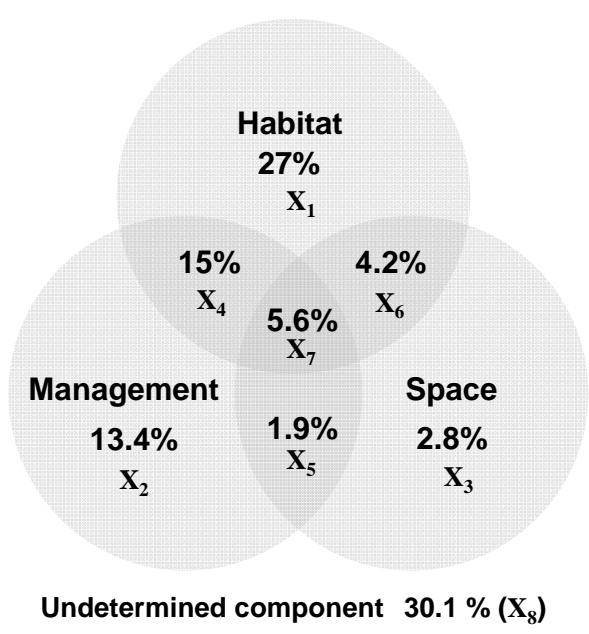

Figure 4. Variation partitioning procedure of microbial community composition, explained by habitat (mean annual temperature and precipitation, radiative dry index, elevation, soil texture, $\mathrm{pH}$, soil $\mathrm{C}$ and $\mathrm{N}$ content, soil $\mathrm{C}: \mathrm{N}$, inorganic $\mathrm{N}$, total PLFAs, water holding capacity), land management (tilled, historically tilled, grazed, flooded) and spatial structure ( $x, y, x y, x^{2}, y^{2}, x^{2} y, x y^{2}, x^{3}, y^{3}$ : the nine terms in which latitudinal $(x)$ and longitudinal $(y)$ coordinates were used to calculate a cubic trend surface) factors.

tent and $\mathrm{pH}$ plotted near the origin, and thus would not be the major drivers of microbial community composition (Fig. 3b).

\subsection{Variation partitioning}

Forward selection of the three groups of environmental factors with CCA suggested that the soil microbial community composition was significantly related to the habitat $\left(\mathrm{X}_{1}\right)$ (mean annual precipitation and temperature, radiative dry index, elevation, soil texture, $\mathrm{pH}$, soil nutrient content, water holding capacity) and land management $\left(\mathrm{X}_{2}\right)$ (tillage, grazing, historical tillage, flooding). The variation partitioning procedure showed that total explained variation in microbial community composition was $69.9 \%$ $\left(\mathrm{X}_{1}+\mathrm{X}_{2}+\mathrm{X}_{3}+\mathrm{X}_{4}+\mathrm{X}_{5}+\mathrm{X}_{6}+\mathrm{X}_{7}\right)$ and undetermined variation in it was $30.1 \%\left(\mathrm{X}_{8}\right)$ (Fig. 4). The largest unique fraction in the explained variation was the effect of habitat $\left(\mathrm{X}_{1}: 27 \%\right)$, which had a strong overlap with land management $\left(\mathrm{X}_{4}: 15 \%\right)$. In addition, the land management effect was also considerable $\left(\mathrm{X}_{2}: 13.4 \%\right)$, whereas the unique effect of spatial structure $\left(\mathrm{X}_{3}: 2.8 \%\right)$ was very small and statistically not significant. 
Table 2. Results of stepwise multiple regression analyses. Independent variables: soil moisture (\%), soil total carbon content (C, \%), mean annual precipitation (MAP), radiative dry index (RDI), soil water holding capacity (WHC). Dependent variables: soil microbial community composition (SMCC), soil total PLFAs (i.e., microbial biomass, TPLFAs; nmol g ${ }^{-1}$ ), percentages of branched PLFAs (gram-positive bacteria) (BP, \%), monounsaturated PLFAs (gram-negative bacteria) (MP, \%), saturated PLFAs (common in microorganism) (SP, \%), fungal PLFAs (F, \%), bacterial PLFAs (B, \%) and fungal : bacterial PLFAs (F:B). Negative values of parameter estimates refer to negative relationships between the examined dependent variables and the independent variables.

\begin{tabular}{llrrr}
\hline & Variable & $\begin{array}{r}\text { Parameter } \\
\text { entered }\end{array}$ & Partial $r^{2}$ & Probability \\
\hline \multirow{2}{*}{ SMCC } & Soil moisture & - & 0.31 & 0.000 \\
& Tillage & - & 0.23 & 0.000 \\
\hline \multirow{2}{*}{ TPLFAs } & Soil moisture & 6.794 & 0.11 & 0.000 \\
& Soil total C & 0.607 & 0.11 & 0.000 \\
& RDI & -26.893 & 0.10 & 0.000 \\
\hline BP & Soil moisture & 0.262 & 0.57 & 0.000 \\
& Tillage & 1.783 & 0.06 & 0.000 \\
\hline MP & Soil moisture & -0.105 & 0.57 & 0.000 \\
& Tillage & -3.800 & 0.17 & 0.000 \\
\hline SP & Soil moisture & 0.329 & 0.49 & 0.000 \\
& RDI & -3.796 & 0.09 & 0.000 \\
\hline F & RDI & 7.074 & 0.57 & 0.000 \\
& Tillage & -1.580 & 0.14 & 0.000 \\
& Soil moisture & -0.042 & 0.06 & 0.000 \\
\hline B & MAP & -0.044 & 0.20 & 0.000 \\
& Soil total C & 1.218 & 0.07 & 0.000 \\
& WHC & 0.158 & 0.06 & 0.000 \\
& Tillage & 1.514 & 0.05 & 0.001 \\
\hline \multirow{2}{*}{ F B } & RDI & 0.142 & 0.42 & 0.000 \\
& Tillage & -0.033 & 0.12 & 0.000 \\
& Soil moisture & -0.002 & 0.11 & 0.000 \\
\hline & & & &
\end{tabular}

\subsection{Soil microbial biomass and contributions of microbial group}

Soil microbial biomass (i.e., total PLFAs) varied 2.4-fold across all the land use types in this region $(P<0.05$, oneway ANOVA; Fig. 5a). The highest value appeared in one of the rangelands (ca. $35 \mathrm{nmol} \mathrm{g}^{-1}$ ), and the lowest value appeared in rice field (ca. $16 \mathrm{nmol} \mathrm{g}^{-1}$ ). Total PLFAs in artificial grassland, grazed rangeland, farmland and returned cropland had intermediate values.

The contributions of each microbial group across seven land use types varied significantly, except that of actinomycetes. Higher contributions of gram-positive bacteria were found in wetter soils, whereas higher contributions of gramnegative bacteria and fungi were observed in drier soils. The contributions of gram-negative bacteria and fungi were lower in heavily disturbed soils than historically disturbed and undisturbed soils $(P<0.05$, one-way ANOVA; Fig. 5a-f). Similar to the variation in fungi, the highest fungal : bacterial PLFAs (ca. 0.35) appeared in one of the rangelands, and the lowest value occurred in rice field (ca. 0.15) (Fig. 5g). Sur- prisingly, the $17 \mathrm{cy}$ : precursor ratio (used as an indicator of the anaerobic stress) across seven land use types fluctuated randomly at this regional scale (Fig. 5h).

Stepwise multiple regression analysis demonstrated that $54 \%$ of the variation in microbial community composition could be explained by soil moisture and tillage. Soil moisture, soil total $\mathrm{C}$ content and radiative dry index together accounted for $32 \%$ of the spatial variation in total microbial biomass. Soil moisture alone contributed to $57 \%$ of the variation in the contributions of both branched and monounsaturated PLFAs. In this region, radiative dry index, soil moisture and tillage together accounted for 77 and $65 \%$ of the variation in the contribution of fungal PLFAs and fungal : bacterial PLFAs. Of the spatial variability in the contribution of bacterial PLFAs, $38 \%$ could be attributed to the combination of precipitation, soil total $\mathrm{C}$ content, water holding capacity and tillage (Table 2). 


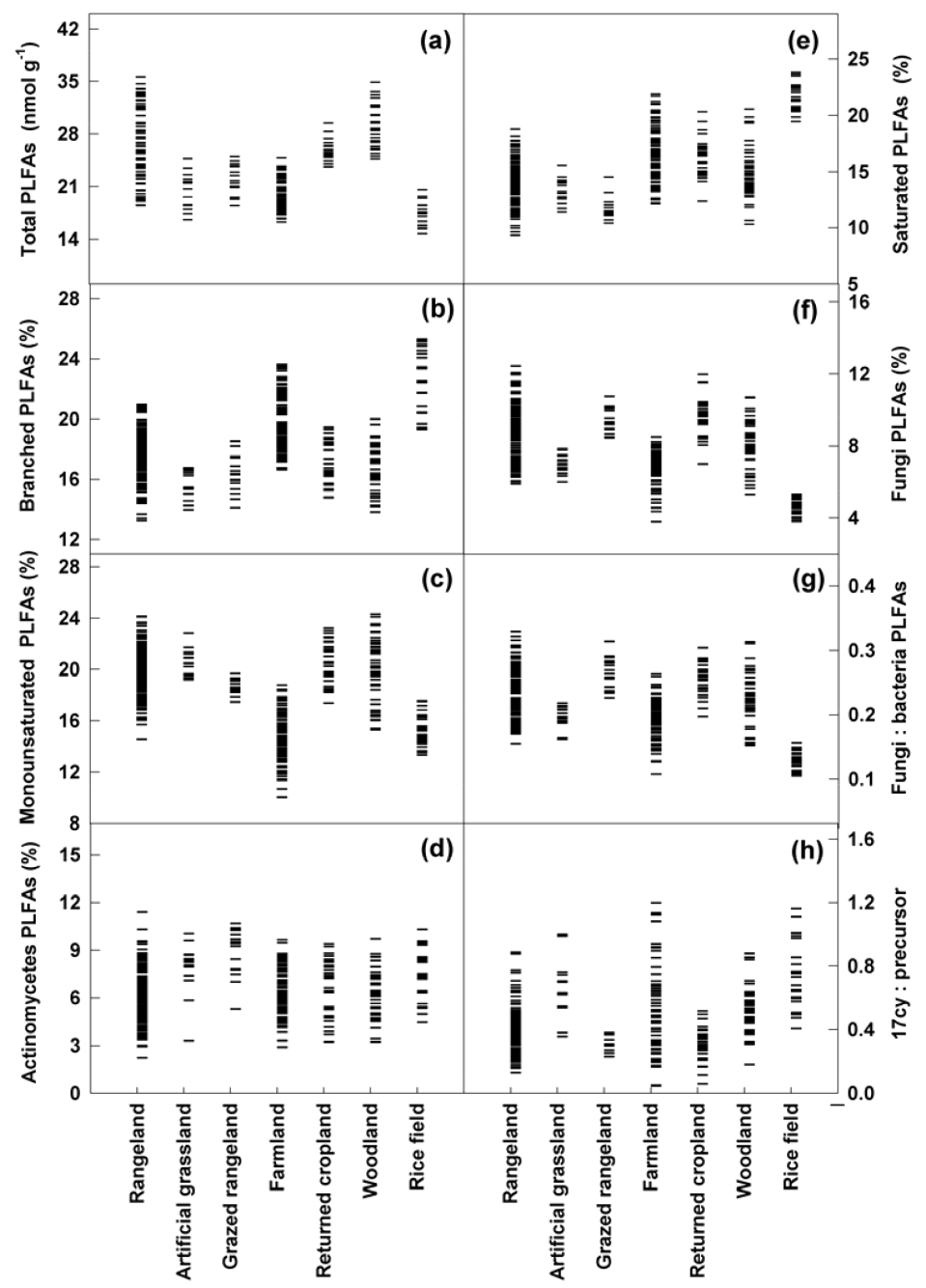

Figure 5. Soil microbial biomass (i.e., total PLFAs), percentages of branched PLFAs (gram-positive bacteria), monounsaturated PLFAs (gram-negative bacteria), actinomycetes (10Me), saturated PLFAs (i.e., common in microorganism), fungi (F), fungal : bacterial PLFAs $(\mathrm{F}: \mathrm{B})$ and $17 \mathrm{cy}$ : precursor across seven land use types at a regional scale in northeastern China.

\section{Discussion}

In the exploration of the primary drivers regulating distributions of soil microbial communities and disentangling relative contributions of multiple environmental factors (e.g., climate, soil texture, $\mathrm{pH}$, soil organic matter content, vegetation type), land management practices and spatial structure on microbial community composition and biomass are important challenges in microbial ecology. In this study, soil moisture is one of the main controls on microbial communities across seven land use types at the regional scale, explaining $31 \%$ of the variation in microbial community composition (Fig. 4; Table 2). Drier soils were more enriched in gram-negative bacteria and fungi, whereas wetter soils were more enriched in gram-positive bacteria (Fig. 5). These findings are in agreement with previous observations (Rinklebe and Langer, 2006; Entry et al., 2008; Clark et al., 2009; Dren- ovsky et al., 2010; Ma et al., 2014). Drought stress likely facilitates increased survival of fungi, because soil fungi rely on more aerobic conditions and are more tolerant of drought due to their filamentous nature (Zhang et al., 2005a). Aerobic filamentous fungi have variable hyphal networks that can relocate water and nutrient resource by cytoplasm translocation (Klein and Paschke, 2004). As soils become water-saturated, soil oxygen levels are reduced, creating an environment favorable for facultative and obligate anaerobic bacteria (Drenovsky et al., 2004).

It has been proposed that the ratio of cyclopropane fatty acids to its precursor can be used to indicate the levels of anaerobic and nutritional stress, because oxygen depletion could trigger conversion of monoenoic fatty acids to cyclopropane fatty acid products (Kieft et al., 1997; Drenovsky et al., 2010). For instance, Drenovsky et al. (2010) reported that cyclopropane fatty acid : precursor ratios $(17 \mathrm{cy}:(16: 1 \omega 7 \mathrm{c})$; 


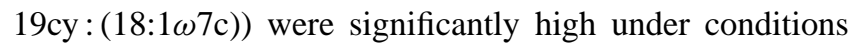
of low $\mathrm{O}_{2}$ concentration and high temperature. However, whether cyclopropane fatty acid is representative of aerobic conditions is debatable. Bossio and Scow (1998) found that the cyclopropane fatty acids were insensitive to water availability across a large-scale precipitation gradient in California. Similarly, our result also show that the $17 \mathrm{cy}$ : precursor responded modestly to high water availability in this region (Fig. 5h), whereas we do not know for sure what limits the formation of cyclopropane. This insensitivity to anaerobic conditions in the soils contrasts with its widespread use as an anaerobic marker. These findings suggest that ratios of cyclopropane fatty acids to its precursor are not generally useful as taxonomic indicators of respiratory type at regional scales.

Distinct microbial community composition and biomass are associated with land disturbance levels and management practices at the regional scale in northeastern China. Continuously farming of land is widely occurring in various biomes across the world. Repeated tillage heavily disturbs soil physical properties and decreases soil bulk density and waterretaining capacity (Bescansa et al., 2006). This frequent disturbance in soil properties during tillage (and associated fertilization) could rapidly alter microbial community composition due to the different competitive ability of specific microbial groups. The groups with the capacity of rapid adaptation to the frequently changing soil environment (e.g., bacteria) could take advantage of new resources in disturbed habitats (Cookson et al., 2008; Sun et al., 2011). Consistent with other large-scale studies, conventional tillage soils had higher proportions of gram-positive bacteria and lower proportions of fungi in this study (Fig. 2b) (Galvez et al., 2001; Zhang et al., 2005a). The ability of gram-positive bacteria to sporulate may allow them to withstand tillage or other anthropogenic disturbance. In contrast, fungi are sensitive to disturbance and their hyphae density would decrease significantly in response to tillage (Drenovsky et al., 2010).

Given the strong effects of heavy disturbance on soil microbial communities, it is interesting to find that microbial community composition in lightly and historically disturbed soils (i.e., grazed rangelands, returned croplands) was similar to that in undisturbed soils. These results are supported by observations in other studies (Bardgett and McAlister, 1999; Ingram et al., 2008; Sun et al. 2011). Ingram et al. (2008) reported that long-term light grazing showed no effect on soil organic $\mathrm{C}$ content and microbial community composition based on concentrations of PLFA biomarkers in a mixed-grass ecosystem. As the disturbance ceased, microbial biomass increased, probably because more time and resources were available for specific microbial groups that have a slower growth rate (e.g., fungi) (Zhang et al., 2005b). However, Buckley and Schmidt (2003) reported that microbial community composition did not differ significantly between conventionally cultivated fields and fields that had been abandoned from cultivation for 9 years. A possible explanation for this result is that long-term sustainable tillage decreases soil C content; thus the recovery of soil organic matter to preagricultural levels may require decades or even centuries.

Many previous studies have demonstrated that vegetation types, soil properties and spatial structure can influence soil microbial community function and abundance through providing suitable habitats and food sources (Kourtev et al., 2003; Šantrucková et al., 2003; Han et al., 2007; Chen et al., 2014), whereas our findings of microbial community composition were not related to these factors across this region. In the current study, soils were sampled in different vegetation types and soil nutrient content, but the microbial community composition was very similar at the same geographical location in natural habitats (e.g., meadow vs. wood and shrub; data not shown) (Fig. 5). Similar trends were observed in heavily disturbed habitats: the distributions of microbial communities depended on land disturbance levels and practices rather than agricultural plant species. For example, the farmland land use types (e.g., corn, peanut, mung bean, red bean) in the same location clustered together in CCA ordination despite the different plant species that they represented (Figs. 2, 3, 5). These results are consistent with the study of Drenovsky et al. (2010), who reported that microbial community composition was more strongly influenced by disturbance than by agricultural plant species in California.

Habitat factors and land management triggered complex interactive effects on soil microbial community composition at the regional scale in northeastern China, as the value of shared variance fraction was $15 \%$ without considering the variation explained by all three components (Fig. 4). This was similar to the findings of Drenovsky et al. (2010) that environmental factors caused significant interactions on microbial community composition at large spatial and temporal scales. The significant shared effects in our study could be attributed to the strong effects of land disturbance (e.g., flooding, irrigation, tillage) on soil properties that then affect microbial communities. The findings suggest that land management could partly control soil environmental effects on microbial community composition and biomass at regional scales.

Inconsistent with the hypothesis, soil moisture and land use were the most important factors driving microbial community composition and biomass at the regional scale in northeastern China. In this study, soil moisture was determined not only by natural precipitation but also by managed inputs; thus the effect of precipitation was weaker but still significant. In addition, factors such as spatial structure, soil texture, $\mathrm{pH}$ and vegetation types did not have significant relationships with microbial community composition and biomass. These findings will improve predictions of the ecological processes and consequences of ecosystems under global changes. 


\section{Appendix A}

Table A1. Sample locations (1-23; see Fig. 1), land use types, land management practices, vegetation types, climatic indices and soil properties. MAP, mean annual precipitation (mm); MAT, mean annual temperature $\left({ }^{\circ} \mathrm{C}\right)$; RDI, radiative dry index; ELE, elevation (m); TC, soil total C (\%); TN, soil total N (\%); SWC, soil water content (\%); WHC, water holding capacity; IN, soil inorganic $\mathrm{N}$ content $\left(\mathrm{mg} \mathrm{kg}^{-1}\right)$; SL, sandy loam; LS, loamy sand.

\begin{tabular}{|c|c|c|c|c|c|c|c|c|c|c|c|c|c|c|c|c|}
\hline Location & No. & Land use type & $\begin{array}{l}\text { Management } \\
\text { practices }\end{array}$ & $\begin{array}{l}\text { Vegetation } \\
\text { type }\end{array}$ & MAP & MAT & RDI & ELE & $\mathrm{pH}$ & $\begin{array}{l}\text { Soil } \\
\text { texture }\end{array}$ & $\mathrm{C}$ & $\mathrm{N}$ & $\mathrm{C}: \mathrm{N}$ & SWC & WHC & IN \\
\hline Baogedawula & 1 & Rangeland & Undisturbed & Desert steppe & 237 & 1.7 & 1.44 & 1092 & 7.7 & LS & 0.67 & 0.12 & 5.32 & 3 & 12 & 2.05 \\
\hline \multirow[t]{2}{*}{ Dabuxiletu } & 2 & Rangeland & Undisturbed & Desert steppe & 276 & 1.4 & 1.37 & 1158 & 7.8 & LS & 0.79 & 0.1 & 7.94 & 5 & 15 & 2.47 \\
\hline & 2 & Grazed rangeland & Grazed & Desert steppe & 276 & 1.4 & 1.37 & 1158 & 7.9 & LS & 0.81 & 0.11 & 7.31 & 5 & 17 & 3.30 \\
\hline \multirow[t]{2}{*}{ Aqiwula } & 3 & Rangeland & Undisturbed & Steppe & 340 & 1.3 & 1.33 & 1239 & 8.8 & SL & 1.45 & 0.15 & 9.78 & 7 & 17 & 3.46 \\
\hline & 3 & Woodland & Undisturbed & Wood and shrub & 340 & 1.3 & 1.33 & 1239 & 7.8 & SL & 0.7 & 0.15 & 4.48 & 9 & 20 & 3.32 \\
\hline Dalainuori & 4 & Rangeland & Undisturbed & Steppe & 385 & 1.3 & 1.21 & 1309 & 8.1 & LS & 0.84 & 0.14 & 7.67 & 8 & 18 & 3.77 \\
\hline Sanyi & 5 & Woodland & Undisturbed & Wood and shrub & 380 & 2.3 & 1.21 & 1173 & 8 & SL & 1.11 & 0.14 & 7.94 & 9 & 22 & 7.70 \\
\hline \multirow[t]{2}{*}{ Xinchengzi } & 6 & Rangeland & Undisturbed & Steppe & 397 & 3.5 & 1.23 & 919 & 7.7 & LS & 1.52 & 0.15 & 10.07 & 10 & 22 & 4.08 \\
\hline & 6 & Returned cropland & Historically tilled & Alfalfa & 397 & 3.5 & 1.23 & 919 & 7.7 & SL & 0.9 & 0.1 & 9.96 & 9 & 23 & 7.79 \\
\hline \multirow{2}{*}{ Xinfuzhilu } & 7 & Grazed rangeland & Grazed & Steppe (site 1) & 386 & 5.8 & 1.18 & 735 & 8.4 & LS & 0.97 & 0.11 & 8.95 & 8 & 25 & 5.87 \\
\hline & 7 & & Grazed & Steppe (site 2) & 386 & 5.8 & 1.18 & 735 & 8.3 & LS & 0.99 & 0.12 & 8.05 & 8 & 25 & 4.84 \\
\hline \multirow[t]{2}{*}{ Tianshan } & 8 & Rangeland & Undisturbed & Steppe & 386 & 5.8 & 1.18 & 513 & 8.3 & LS & 1.66 & 0.19 & 8.48 & 8 & 23 & 6.14 \\
\hline & 8 & Returned cropland & Historically tilled & Almond & 386 & 5.8 & 1.18 & 513 & 8.2 & SL & 0.9 & 0.1 & 8.71 & 10 & 25 & 13.08 \\
\hline \multirow[t]{2}{*}{ Tianshan } & 9 & Rangeland & Undisturbed & Steppe & 388 & 5.8 & 1.18 & 413 & 8.2 & LS & 1.63 & 0.19 & 8.36 & 9 & 22 & 5.24 \\
\hline & 9 & Returned cropland & Historically tilled & Almond & 388 & 5.8 & 1.18 & 413 & 8.2 & SL & 1.81 & 0.17 & 10.78 & 10 & 24 & 7.34 \\
\hline \multirow[t]{3}{*}{ Shaogen } & 10 & Rangeland & Undisturbed & Steppe (site 1) & 385 & 6.8 & 1.12 & 270 & 8 & LS & 0.85 & 0.11 & 7.66 & 12 & 25 & 5.14 \\
\hline & 10 & & Undisturbed & Steppe (site 2) & 385 & 6.8 & 1.12 & 270 & 8.2 & LS & 1 & 0.11 & 9.36 & 11 & 25 & 4.58 \\
\hline & 10 & Farmland & Tilled & Corn & 385 & 6.8 & 1.12 & 270 & 8.6 & LS & 0.9 & 0.11 & 8.08 & 11 & 24 & 20.80 \\
\hline \multirow[t]{3}{*}{ Molimiao } & 11 & Rangeland & Undisturbed & Steppe (site 1) & 399 & 6.3 & 1.05 & 179 & 8.4 & SL & 1.05 & 0.12 & 8.85 & 12 & 25 & 7.52 \\
\hline & 11 & & Undisturbed & Steppe (site 2) & 399 & 6.3 & 1.05 & 179 & 8.4 & SL & 1.1 & 0.15 & 7.30 & 13 & 25 & 6.65 \\
\hline & 11 & Farmland & Tilled & Corn & 399 & 6.3 & 1.05 & 179 & 8.4 & SL & 1 & 0.11 & 9.13 & 10 & 25 & 6.34 \\
\hline Yuxin & 12 & Rice field & Periodically flooded & Rice & 397 & 6.3 & 1.02 & 211 & 7.8 & SL & 1.23 & 0.15 & 8.23 & 32 & 32 & 5.23 \\
\hline Baixingtu & 13 & Woodland & Undisturbed & Wood and shrub & 414 & 6 & 1.02 & 159 & 7.7 & SL & 0.97 & 0.12 & 8.08 & 13 & 28 & 8.85 \\
\hline \multirow[t]{3}{*}{ Baolongshan } & 14 & Rangeland & Undisturbed & Meadow (site 1) & 415 & 6 & 1 & 156 & 7.9 & SL & 1.3 & 0.13 & 9.02 & 13 & 26 & 8.45 \\
\hline & 14 & & Undisturbed & Meadow (site 2) & 415 & 6 & 1 & 156 & 7.8 & SL & 1.34 & 0.15 & 8.43 & 13 & 27 & 7.62 \\
\hline & 14 & Farmland & Tilled & Corn & 415 & 6 & 1 & 156 & 7.7 & SL & 1.3 & 0.11 & 11.92 & 12 & 27 & 6.24 \\
\hline \multirow[t]{4}{*}{ Jiamatu } & 15 & Rangeland & Undisturbed & Meadow (site 1) & 422 & 6 & 1 & 149 & 8.2 & SL & 1.73 & 0.17 & 10.20 & 14 & 27 & 6.08 \\
\hline & 15 & & Undisturbed & Meadow (site 2) & 422 & 6 & 1 & 149 & 8.3 & SL & 1.77 & 0.18 & 10.07 & 13 & 28 & 6.22 \\
\hline & 15 & Farmland & Tilled & Corn & 422 & 6 & 1 & 149 & 8.2 & SL & 1.22 & 0.17 & 7.19 & 11 & 25 & 10.34 \\
\hline & 15 & & Tilled & Red bean & 422 & 6 & 1 & 149 & 8.4 & SL & 1 & 0.17 & 5.56 & 10 & 25 & 18.35 \\
\hline \multirow[t]{2}{*}{ Taipingchuan } & 16 & Rangeland & Undisturbed & Meadow & 428 & 5.6 & 0.97 & 150 & 8.6 & LS & 1.02 & 0.13 & 8.07 & 18 & 31 & 7.37 \\
\hline & 16 & Rice field & Periodically flooded & Rice & 428 & 5.6 & 0.97 & 150 & 8.3 & SL & 1.18 & 0.12 & 9.83 & 35 & 35 & 8.93 \\
\hline \multirow[t]{3}{*}{ Yaojingzinan } & 17 & Woodland & Undisturbed & Wood and shrub (site 1) & 435 & 5.4 & 0.97 & 150 & 7.9 & SL & 0.98 & 0.13 & 7.27 & 14 & 29 & 5.78 \\
\hline & 17 & Woodland & Undisturbed & Wood and shrub (site 2) & 435 & 5.4 & 0.97 & 150 & 7.9 & SL & 1.16 & 0.16 & 7.27 & 13 & 28 & 5.78 \\
\hline & 17 & Farmland & Tilled & Peanut & 435 & 5.4 & 0.97 & 150 & 7.5 & LS & 0.9 & 0.15 & 5.97 & 10 & 30 & 3.23 \\
\hline \multirow[t]{5}{*}{ Yaojingzi } & 18 & Rangeland & Undisturbed & Meadow (site 1) & 435 & 5.4 & 0.97 & 159 & 7.8 & SL & 1.16 & 0.16 & 7.19 & 17 & 30 & 4.47 \\
\hline & 18 & & Undisturbed & Meadow (site 2) & 435 & 5.4 & 0.97 & 159 & 7.7 & SL & 0.82 & 0.11 & 9.43 & 18 & 30 & 5.25 \\
\hline & 18 & Farmland & Tilled & Peanut & 435 & 5.4 & 0.97 & 159 & 7.5 & LS & 1.03 & 0.13 & 7.96 & 17 & 30 & 4.75 \\
\hline & 18 & & Tilled & Mung bean & 435 & 5.4 & 0.97 & 159 & 7.6 & SL & 1.17 & 0.15 & 7.73 & 17 & 31 & 5.75 \\
\hline & 18 & & Tilled & Corn & 435 & 5.4 & 0.97 & 159 & 7.8 & SL & 1 & 0.12 & 8.69 & 20 & 32 & 5.95 \\
\hline Yaojingzi & 19 & Rangeland & Undisturbed & Meadow & 434 & 5.4 & 0.97 & 165 & 8.4 & SL & 2.21 & 0.23 & 9.66 & 23 & 34 & 8.38 \\
\hline Yaojingzi & 20 & Artificial grassland & Tilled & Meadow (site 1) & 433 & 5.4 & 0.97 & 140 & 8.1 & SL & 1.85 & 0.19 & 9.91 & 14 & 33 & 6.44 \\
\hline & 20 & & Tilled & Meadow (site 2) & 433 & 5.4 & 0.97 & 140 & 8.1 & SL & 1.9 & 0.19 & 9.98 & 12 & 33 & 5.62 \\
\hline & 20 & Farmland & Tilled & Corn & 433 & 5.4 & 0.97 & 140 & 8.1 & SL & 0.92 & 0.1 & 9.23 & 18 & 32 & 8.23 \\
\hline Wulanaodu & 21 & Rangeland & Undisturbed & Meadow (site 1) & 442 & 5.3 & 0.93 & 152 & 8.1 & SL & 1.25 & 0.16 & 7.89 & 22 & 33 & 4.23 \\
\hline & 21 & & Undisturbed & Meadow (site 2) & 442 & 5.3 & 0.93 & 152 & 8.1 & SL & 1.3 & 0.16 & 8.03 & 19 & 34 & 4.87 \\
\hline & 21 & Farmland & Tilled & Corn & 442 & 5.3 & 0.93 & 152 & 8.2 & SL & 1.74 & 0.24 & 7.02 & 20 & 32 & 4.12 \\
\hline & 21 & Woodland & Undisturbed & Wood and shrub & 442 & 5.3 & 0.93 & 152 & 7.5 & SL & 1.87 & 0.23 & 8.11 & 20 & 34 & 6.55 \\
\hline Chaganhua & 22 & Rangeland & Undisturbed & Meadow (site 1) & 467 & 5.1 & 0.93 & 202 & 8.5 & LS & 1.54 & 0.2 & 7.67 & 24 & 36 & 4.32 \\
\hline & 22 & & Undisturbed & Meadow (site 2) & 467 & 5.1 & 0.93 & 202 & 8.4 & LS & 1.42 & 0.19 & 7.44 & 22 & 36 & 5.01 \\
\hline Wulantuga & 23 & Rangeland & Undisturbed & Meadow & 472 & 5.1 & 0.91 & 291 & 8.5 & SL & 2.16 & 0.2 & 10.63 & 23 & 34 & 4.85 \\
\hline & 23 & Farmland & Tilled & Corn & 472 & 5.1 & 0.91 & 291 & 8.2 & SL & 1.73 & 0.24 & 7.36 & 22 & 33 & 7.75 \\
\hline & 23 & & Tilled & Peanut & 472 & 5.1 & 0.91 & 291 & 7.9 & SL & 1.72 & 0.23 & 7.76 & 22 & 32 & 3.52 \\
\hline & 23 & Woodland & Undisturbed & Wood and shrub & 472 & 5.1 & 0.91 & 291 & 7.8 & SL & 1.63 & 0.19 & 8.75 & 18 & 35 & 7.39 \\
\hline
\end{tabular}


Acknowledgements. We are grateful for the funding provided by the Natural Science Foundation of China (nos. 31170304, 31070228 and 31300440 ). We also wish to thank the four anonymous reviewers for their constructive comments, which helped in improving the manuscript.

Edited by: S. Fontaine

\section{References}

Bardgett, R. D. and McAlister, E.: The measurement of soil fungal: bacterial biomass ratios as an indicator of ecosystem selfregulation in temperate meadow grasslands, Biol. Fert. Soils, 29, 282-290, 1999.

Bescansa, P., Imaz, M. J., Virto, I., Enrique, A., and Hoogmoed, W. B.: Soil water retention as affected by tillage and residue management in semiarid Spain, Soil Till. Res., 87, 19-27, 2006.

Borcard, D., Legendre, P., and Drapeau, P.: Partialling out the spatial component of ecological variation, Ecology, 73, 1045-1055, 1992.

Bossio, D. A. and Scow, K. M.: Impacts of carbon and flooding on soil microbial communities: phospholipid fatty acids profiles and substrate utilization patterns, Microb. Ecol., 35, 265-278, 1998.

Brockett, B. F. T., Prescott, S. J., and Grayston, S. J.: Soil moisture is the major factor influencing microbial community structure and enzyme activities across seven biogeoclimatic zones in western Canada, Soil Biol. Biochem., 44, 9-20, 2012.

Buckley, D. H. and Schmidt, T. M.: Diversity and dynamics of microbial communities in soils from agro-ecosystems, Environ. Microb., 5, 441-452, 2003.

Carletti, P., Vendramin, E., Pizzeghello, D., Concheri, G., Zanella, A., Nardi, S., and Squartini, A.: Soil humic compounds and microbial communities in six spruce forests as function of parent material, slope aspect and stand age, Plant Soil, 315, 47-65, 2009.

Chen, D. M., Mi, J., Chu, P. F., Cheng, J. H., Zhang, L. X., Pan, Q. M., Xie, Y. C., and Bai, Y. F.: Patterns and drivers of soil microbial communities along a precipitation gradient on the Mongolian Plateau, Landscape Ecol., doi:10.1007/s10980-014-9996-z, 2014.

Clark, J. S., Campbell, J. H., Grizzle, H., Acosta-Martinez, V., and Zak, J. C.: Soil microbial community response to drought and precipitation variability in the Chihuahuan desert, Microb. Ecol., 57, 248-260, 2009.

Cookson, W. R., Murphy, D. V., and Roper, M. M.: Characterizing the relationships between soil organic matte components and microbial function and composition along a tillage disturbance gradient, Soil Biol. Biochem., 40, 763-777, 2008.

Drenovsky, R. E., Vo, D., Graham, K. J., and Scow, K. M.: Soil water content and organic carbon availability are major determinants of soil microbial community composition, Microb. Ecol., 48, 424-430, 2004.

Drenovsky, R. E., Steenwerth, K. L., Jackson, L. E., and Scow, K. M.: Land use and climatic factors structure regional patterns in soil microbial communities, Global Ecol. Biogeogr., 19, 27-39, 2010.

Eskelinen, A., Stark, S., and Männistö, M.: Links between plant community composition, soil organic matter quality and micro- bial communities in contrasting tundra habitats, Oecologia, 161, 113-123, 2009.

Entry, J. A., Mills, D., Mathee, K., Jayachandran, K., Sojka, R. E., and Narasimhan G.: Influence of irrigated agriculture on soil microbial diversity, Appl. Soil Ecol., 40, 146-154, 2008.

Evans, D. G. and Miller, M. H.: The role of the external mycelial network in the effect of soil disturbance upon vesiculararbuscular mycorrhizal colonization of maize, New Phytol., 114, 65-71, 1990.

Fierer, N. and Jackson, R. B.: The diversity and biogeography of soil bacterial communities, Pro. Natl. Acad. Sci., 103, 626-631, 2006.

Frostegård, A., Bååth, E., and Tunlid, A.: Shifts in the structure of soil microbial communities in limed forests as revealed by phospholipid fatty acid analysis, Soil Biol. Biochem., 25, 723-730, 1993.

Frostegård, A. and Bååth, E.: The use of phospholipid fatty acid analysis to estimate bacterial and fungal biomass in soil, Biol. Fert. Soils, 22, 59-65, 1996.

Frostegård, A., Tunlid, A., and Bååth, E.: Use and misuse of PLFA measurements in soils, Soil Biol. Biochem., 43, 1621-1625, 2011.

Galvez, L., Douds, D. D., Drinkwater, L. E., and Wagoner, P.: Effect of tillage and farming system upon VAM fungus populations and mycorrhizas and nutrient uptake of maize, Plant Soil, 228, 299 308, 2001.

Hackl, E., Pfeffer, M., Donat, C., Bachmann, G., and ZechmeisterBoltenstern, S.: Composition of the microbial communities in the mineral soil under different types of natural forest, Soil Biol. Biochem., 37, 661-671, 2005.

Han, X. M., Wang, R. Q., Liu, J., Wang, M. C., Zhou, J., and Guo, W. H.: Effects of vegetation type on soil microbial community structure and catabolic diversity assessed by polyphasic methods in North China, J. Environ. Sci., 19, 1228-1234, 2007.

Harris, J.: Soil microbial communities and restoration ecology: facilitators or followers?, Science, 325, 573-574, 2009.

Ingram, L. J., Stahl, P. D., Schuman, G. E., Buyer, J. S., Vance, G. F., Ganjegunte, G. K., Welker, J. M., and Derner, J. D.: Grazing impacts on soil carbon and microbial communities in a mixedgrass ecosystem, Soil Sci. Soc. Am. J., 72, 939-948, 2008.

Kaiser, C., Fuchslueger, L., Koranda, M., Gorfer, M., Stange, C. F., Kitzler, B., Rasche, F., Strauss, J., Sessitsch, A., Boltenstern, S. Z., and Richter, A.: Plants control the seasonal dynamics of microbial $\mathrm{N}$ cycling in a beech forest soil by belowground $\mathrm{C}$ allocation, Ecology, 92, 1036-1051, 2011.

Kieft, T. L., Wilch, E., O’Connor, K., Ringelberg, D. B., and White, D. C.: Survival and phospholipid fatty acid profiles of surface and subsurface bacteria in natural sediment microcosms, Appl. Environ. Microb., 63, 1531-1542, 1997.

Klein, D. A. and Paschke, M. W.: Filamentous fungi: the indeterminate lifestyle and microbial ecology, Microb. Ecol., 47, 224-235, 2004.

Knivett, V. A. and Cullen, J.: Some factors affecting cyclopropane acid formation in Escherichia coli, Biochem. J., 96, 771-776, 1965.

Koch, G. W., Vitousek, P. M., Steffen, W. L., and Walker, B. H.: Terrestrial transects for global change research, Vegetatio, 121 , 53-65, 1995. 
Kreft, H. and Jetz, W.: Global patterns and determinants of vascular plant diversity, Pro. Natl. Acad. Sci., 104, 5925-5930, 2007.

Legendre, P.: Quantitative methods and biogeographic analysis, in: Evolutionary Biogeography of the Marine Algae of the North Atlantic, edited by: Garbary, D. J. and South, G. R., SpringerVerlag, Berlin, 9-43, 1990.

Lepš, J. and Šmilauer, P.: Multivariate analysis of ecological data using canoco, Cambridge University Press, Cambridge, 2003.

Ma, L., Guo, C., Xin, X., Yuan, S., and Wang, R.: Effects of belowground litter addition, increased precipitation and clipping on soil carbon and nitrogen mineralization in a temperate steppe, Biogeosciences, 10, 7361-7372, doi:10.5194/bg-10-7361-2013, 2013.

Ma, L., Yuan, S., Guo, C., and Wang, R.: Carbon and nitrogen dynamics of native Leymus chinensis grasslands along a $1000 \mathrm{~km}$ longitudinal precipitation gradient in northeastern China, Biogeosciences, 11, 7097-7106, doi:10.5194/bg-117097-2014, 2014.

Ni, J. and Zhang, X. S.: Climate variability, ecological gradient and the northeast China transect (NECT), J. Arid Environ., 46, 313$325,2000$.

Nielsen, U. N., Osler, G. H. R., Campbell, C. D., Burslem, D. F. R. P., and van der Wal, R.: The influence of vegetation type, soil properties and precipitation on the composition of soil mite and microbial communities at the landscape scale, J. Biogeogr., 37, 1317-1328, 2010.

Pasternak, Z., Al-Ashhab, A., Gatica, J., Gafny, R., Avraham, S., Minz, D., Gillor, O., and Jurkevitch, E.: Spatial and temporal biogeography of soil microbial communities in arid and semiarid regions, PLoS ONE, 8, e69705, doi:10.1371/journal.pone.0069705, 2013.

Rinklebe, J. and Langer, U.: Microbial diversity in three floodplain soils at the Elbe River (Germany), Soil Biol. Biochem., 38, 2144 2151, 2006.

Šantrucková, H., Bird, M.I., Kalaschnikov, Y.N., Grund, M., Elhottová, D., and Šimek, M.: Microbial characteristics of soils on a latitudinal transect in Siberia, Global Change Biol., 9, 11061117, 2003.

Scanlon, B. R., Jolly, I., Sophocleous, M., and Zhang, L.: Global impacts of conversions from natural to agricultural ecosystems on water resources: quantity vs. quality, Water Resour. Res., 43, 1-18, 2007.

Sun, B., Hallett, P. D., Caul, S., Daniell, T. J., and Hopkins, D. W.: Distribution of soil carbon and microbial biomass in arable soils under different tillage regimes, Plant Soil, 338, 17-25, 2011.
Tsiknia, M., Paranychianakis, N. V., Varouchakis, E. A., Moraetis, D., and Nikolaidis, N. P.: Environmental drivers of soil microbial community distribution at the Koiliaris Critical Zone Observatory, Microb. Ecol., 99, 139-152, 2014.

Wang, R. Z. and Gao, Q.: Climate-driven changes in shoot density and shoot biomass in Leymus chinensis (Poaceae) on the northeast China transect (NECT), Global Ecol. Biogeogr., 12, 249259, 2003.

Wang, R. Z., Huang, W. W., Chen, L., Ma, L. N., Guo, C. Y., and Liu, X. Q.: Anatomical and physiological plasticity in Leymus chinensis (Poaceae) along large-scale longitudinal gradient in northeast China, PLoS One, 6, e26209, doi:10.1371/journal.pone.0026209, 2011.

Wardle, D. A., Bardgett, R. D., Klironomos, J. N., Setälä, H., van der Putten, W. H., and Wall, D. H.: Ecological linkages between aboveground and belowground biota, Science, 304, 1629-1633, 2004.

White, D. C., Davis, W. M., Nickels, J. S., King, J. D., and Bobbie, R. J.: Determination of the sedimentary microbial biomass by extractible lipid phosphate, Oecologia, 40, 51-62, 1979.

Wilcox, J. C.: Rate of soil drainage following an irrigation: A new concept of the upper limit of available moisture, Can. J. Soil Sci., 42, 122-128, 1962.

Yang, Y. F., Wu, L. W., Liu, Q. Y., Yuan, M. T., Xu, D. P., Yu, H., Hu, Y. G., Duan, J. C., Li, X. Z., He, Z. L., Xue, K., Nostrand, J. V., Wang, S. P., and Zhou, J. Z.: Responses of the functional structure of soil microbial community to livestock grazing in the Tibetan alpine grassland, Glob. Change Biol., 19, 637-486, 2013.

Zhang, W., Parker, K. M., Luo, Y., Wan, S., Wallace, L. L., and Hu, S.: Soil microbial responses to experimental warming and clipping in a tallgrass prairie, Global Change Biol., 11, 266-277, 2005a.

Zhang, W. J., Rui, W. Y., Tu, C., Diab, H. G., Louws, F. J., Mueller, J. P., Creamer, N., Bell, M., Wagger, M. G., and Hu, S.: Responses of soil microbial community structure and diversity to agricultural deintensification, Pedosphere, 15, 440-447, 2005b.

Zhang, X. S., Gao, Q., Yang, D. A., Zhou, G. S., Ni, J., and Wang, Q.: A gradient analysis and prediction on the Northeast China Transect (NECT) for global change study, Acta Bot. Sin., 39, 785-799, 1997.

Zinger, L., Lejon, D. P. H., Baptist, F., Bouasria, A., Aubert, S., Geremia, R. A., and Choler, P.: Contrasting diversity patterns of crenarchaeal, bacterial and fungal soil communities in an alpine landscape, PLoS ONE, 6, e19950, doi:10.1371/journal.pone.0019950, 2011. 